Последние технологии.

К ним относится встроенный в таблетки радиопередатчик, который будет напоминать о приеме лекарства. Особенно ценно применение подобной конструкции в детском и старческом возрасте.

Плавучие препараты - уникальный автомат размером в несколько микронов доставит необходимый препарат в нужное место, независимо от вязкости крови. Существует пока только в разработке.

Таким образом, в современных условиях инновационные лекарственные формы очень сильно развиваются и совершенствуются.

$$
* * *
$$

1. Использование полимерных аппликационных антибактериальных пленок для лечения больных с перфоративными одонтогенными верхнечелюстными синуситами / Лазарев А.И., Честникова С.Э., Ерофеева Л.Н., Панкрушева Т.А. // Российская оториноларингология. 2017. № 2. С. 3-6.

2. Панкрушева Т.А., Автина Н.В., Панкрушев А.А. Лекарственные формы, используемые в местной терапии воспалительных заболеваний пародонта // Вестник новых медицинских технологий. 2019. Т. 16. № 1. С. 139141.

3. Полимерные лекарственные пленки для лечения заболеваний слизистых оболочек / Панкрушева Т.А., Ерофеева Л.Н., Маравина И.Н., Чекмарева М.С., Автина Т.В., Автина Н.В. // Ученые записки Орловского государственного университета. Серия: Естественные, технические и медицинские науки. 2019. Т. 1. № 7. С. 211-212.

4. Мамедьяров 3.А. Инновационное развитие глобальной фармацевтической отрасли: дис. канд. экон. наук: 08.00.14. - М., 2019. - 182 c.

\title{
Гегирова А.X.
}

Лекарственные растения, обладающие ранозаживляющим и кровоостанавливающим действием

Северо-Осетинский государственный университет имени К.Л.Хетагурова (Россия, Владикавказ)

doi: 10.18411/trnio-01-2022-207

\section{Аннотация}

Все существующие и изучаемые в настоящее время лекарственные растения имеют разнообразный химический состав и содержат большое количество веществ (биологически активных и индифферентных). Спектр фармакологической активности растений можно определить по наличию достаточного количества химических веществ, которые, в свою очередь, могут принадлежать к разным классам и группам, но присутствуют в разных количествах в каждом растении. Это такие вещества, как эфирные масла, дубильные вещества, флавоноиды, сапонины и многие другие. А количество этих веществ в лекарственном растении может колебаться от десятков до сотен. Это связано с тем, что в определенном растении преобладает определенное вещество с определенным фармакологическим действием, которое используют для лечения или предотвращения определенного заболевания.

Каждый человек в своей жизни сталкивался с такой проблемой, как раны, разного характера. Получить какое-либо повреждение тканей, например разрезать, разорвать или поджечь довольно легко. Но восстановить и вылечить рану потребует времени. Помимо повреждений раны могут сопровождаться различными воспалительными процессами. Так же нужно обратить внимание на то, что через пораженную ткань в организм человека могут попасть различные микроорганизмы, вызывая при этом достаточно большое многообразие инфекций. Поэтому раны - это серьезная проблема, которая требует своевременного лечения.
Ключевые
слова:
лекарственные
растения,
ранозаживляющие,

кровоостанавливающие. 
Abstract

All currently existing and studied medicinal plants have a varied chemical composition and contain a large number of substances (biologically active and indifferent). The spectrum of pharmacological activity of plants can be determined by the presence of a sufficient amount of chemicals, which, in turn, may belong to different classes and groups, but are present in different quantities in each plant. These are substances such as essential oils, tannins, flavonoids, saponins and many others. And the amount of these substances in a medicinal plant can range from tens to hundreds. This is due to the fact that a certain substance with a certain pharmacological action predominates in a certain plant, which is used to treat or prevent a certain disease.

Each person in his life has faced such a problem as wounds of a different nature. It is quite easy to get any tissue damage, such as cutting, tearing or burning. But it will take time to repair and heal the wound. In addition to damage, wounds can be accompanied by various inflammatory processes. You also need to pay attention to the fact that various microorganisms can enter the human body through the affected tissue, causing a fairly large variety of infections. Therefore, wounds are a serious problem that requires timely treatment.

Keywords: medicinal plants, wound healing, hemostatic.

Для лечения ран используют лекарственные растения, обладающие не только ранозаживляющим и кровоостанавливающим эффектом, но и бактерицидным, а также обеззараживающим действием.

Кровоостанавливающий эффект гемостатических средств резорбтивного действия достигается при поступлении веществ данной группы непосредственно в кровь. Широкое применение данной группы получили такие вещества, как витамин К, каротин, берберин и др.

Витамин К важен для нормального процесса свертывания крови, принимает участие в образовании протромбина в печени. При недостатке этого витамина может возникнуть мелкие подкожные или внутримышечные кровоизлияния. А если у человека случилось травма, может быть сильное кровотечение, что опасно для жизни.

Алкалоиды в лекарственных растениях содержатся в виде солей органических кислот. Берберин наиболее известный и распространенный алкалоид в лекарственных растениях различных групп.

Данный алкалоид обладает выраженным успокаивающим и кровоостанавливающим действием. Также многочисленные исследования показали, что берберин обладает помимо кровоостанавливающего эффекта значительной антибактериальной, противогрибковой и противопротозойной активностью. Таким образом, берберин препятствует связыванию болезнетворных микробов с клетками человеческого организма, предотвращая при этом развитие многих инфекционных заболеваний.

Помогает улучшить проницаемость капилляров, сердечно-сосудистую деятельность и спазмы пищеварительного тракта.

Флаваноиды обладают антибактериальным или антимикробным действием. Например, такие флаваноиды, как рутин и кверцетин, используются в качестве средств заживления ран и кровоостанавливающих средств. Их еще называют витамином Р. Если сочетать данные флаваноиды с аскорбиновой кислотой, то они тормозят процесс свертываемости крови и повышает эластичность эритроцитов.

Отличительным эффектом дубильных веществ от других является то, что они могут дубить кожу, при этом отнимают способность ее к гниению и затвердеванию при высыхании.

Танин самое распространенное дубильное вещество. Обладает противовоспалительным действием, а также способствует свертыванию белков с образованием защитной пленки, поэтому применение его как кровоостанавливающее средство вполне рационально. 
Важное место среди кровоостанавливающих и ранозаживляющих средств имеют лекарственные растения и приготавливаемые препараты из них. Они очень эффективны в лечении ран и кровотечений.

Ярко выраженным кровоостанавливающим эффектом обладает лекарственное растение Лагохилус опьяняющий. Листья данного лекарственного растения содержат лагохилин, эфирные масла - 0,04\%, дубильные вещества - $15 \%$, органические кислоты, каротин, витамины С и К.

Горец перечный известен своими целебными свойствами еще во времена Парацельса. Но как кровоостанавливающее средство он начал применяться с начала 20-го века. В траве горца находятся дубильные вещества, флавонольные производные (рутин, гиперозид, рамназин и др.), эфирные масла, органические кислоты, витамины С и К.

Хорошим кровоостанавливающим действием обладает Калина обыкновенная. Кровоостанавливающий эффект калины обусловлен тем, что в коре данного растения содержится достаточное количество витамина К, гликозида вибурнина, сложные эфиры и дубильные вещества. Также помимо кровоостанавливающего действия, кора калины обладает спазмолитическим, успокаивающим и вяжущим действием.

Пастушья сумка содержит значительное количество витамина К, аскорбиновой кислоты, амины: холин, ацетилхолин, тирамин и гистамин.

Крапива двудомная очень распространена и легкодоступна. Состав листьев крапивы очень богат витамином $\mathrm{K}-0,3 \%$, витамин $\mathrm{C}-0,5 \%$, каротиноиды $-50 г$, гликозид уртицин, дубильные вещества и др. Этим составом и обусловлено его кровоостанавливающее и ранозаживляющее действие.

Также используют Плоды облепихи. Но помимо необходимых ранозаживляющих эффектов, облепиха является спазмолитическим и противовоспалительным средством. В плодах облепихи содержатся провитамин А до 10 мг\% и витамин К, дубильные вещества, кверцетин, жирное масло.

$$
* * *
$$

1. Государственная фармакопея. - 14-е изд. - М.: Медицина: Вып.1 Характеристика ЛРС

2. Государственная фармакопея: Вып.2 Общие методы анализа. Лекарственное растительное сырье. - 14-е изд. - М.: Медицина

3. Лекарственные растения. - Спб.: ООО «СЗКЭО», 2016. - 320 С.: ил. Под редакции А.Шаронов.

4. Энциклопедия лекарственных растений. - Вильнюс, UAB «Bestiary», 2018.- 224 с.: ил. Под редакцией С.Ю. Афонькин.

5. Википедия - Свободная энциклопедия \l: http:www:wikipedia.org.

6. Лекарственные растительные сборы / Л.Г. Марченко [и др.]. - СПб.: Питер, 2016. - 88 с.

\section{Дзидзоева М.И. \\ Производство БАД. Нормативная документация. Основы технологии и контроля качества БАД}

Северо-Осетинский государственный университет им.К.Л.Хетагурова

(Россия, Владикавказ)

doi: 10.18411/trnio-01-2022-208

\section{Аннотация}

В статье проведен анализ производства БАД. Исследована нормативная документация по заданному вопросу. Проведен анализ основных технологий и контроля качества БАД.

Ключевые слова: БАД, технология, качество, производство, формы, медицина.

\section{Abstract}

The article analyzes the production of dietary supplements. The normative documentation on the given question is investigated. The analysis of the main technologies and quality control of dietary supplements is carried out.

Keywords: dietary supplements, technology, quality, production, forms, medicine. 